\title{
Factors of Pharmacy Practice on Pharmacy Technician Job Satisfaction in Saudi Arabia
}

\author{
Yousef Ahmed Alomi* iD, The \\ Former General Manager of General \\ Administration of Pharmaceutical Care, \\ Former Head, National Clinical Pharmacy \\ and Pharmacy Practice, Former Head, \\ Pharmacy R\&D Administration, Ministry of \\ Health, Riyadh, SAUDI ARABIA. \\ Faiz A. Bahadig Rph, Informatics Phar- \\ macist, Pharmaceutical Care Department, \\ King Abdul-Aziz Medical, City-WR-Jeddah, \\ Ministry of National Guard, SAUDI ARABIA. \\ Bayan Ibrahim Alghuraybi, Pharmacy \\ Services, Prince Sultan Military Medical City, \\ Riyadh, SAUDI ARABIA. \\ Budoor Emad Aloumi, Pharmacist, \\ Pharmaceutical Care Services, Ministry of \\ National Guard - Health Affairs. KAMC - \\ Central Region, SAUDI ARABIA. \\ Reem Saad Alsubaie, Pharmacy Ser- \\ vices, Prince Sultan Military Medical City, \\ Riyadh, SAUDI ARABIA.
}

\section{Correspondence:}

Yousef Ahmed Alomi, (Bsc. Pharm, MSC. Clin Pharm, BCPS, BCNSP, DiBA, CDE) The Former General Manager of General Administration of Pharmaceutical Care, Former Head, National Clinical Pharmacy and Pharmacy Practice, Former Head, Pharmacy R\&D Administration, Ministry of Health, Riyadh, SAUDI ARABIA.

Phone no: +966 504417712

E-mail:yalomi@gmail.com

Received: 11-02-2019;

Accepted: 29-04-2019

Copyright: (c) the author(s),publisher and licensee Pharmacology, Toxicology and Biomedical Reports. This is an open-access article distributed under the terms of the Creative Commons Attribution NonCommercial License, which permits unrestricted non-commercial use, distribution, and reproduction in any medium, provided the original work is properly cited.

This is an open access article distributed under the terms of the Creative Commons Attribution-NonCommercial-ShareAlike 4.0 License

Access this article online

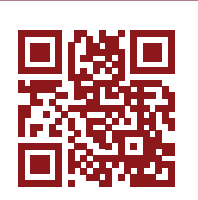

www.ptbreports.org

DOI:

10.5530/PTB.2019.5.27

\begin{abstract}
Purpose: To explore the Pharmacy practice factors on pharmacy technician job satisfaction in Saudi Arabia. Methods: It is a 4-months cross-section survey of the stress factors impact of pharmacy technician job satisfaction in Saudi Arabia. The study consisted of 35 questions divided into two-part demographic information and the second part consisted of three parts. Part one was about stress-related factors of pharmacy job. It included pharmacy management policies, pharmacy stress factors, pharmacy personal time, salary and benefits, pharmacy motivation factors. Part two included the questions about pharmacy services units of pharmacy job. It included pharmacy management structure, dispersing and patient education, clinical pharmacy services, pharmacy technology, pharmacy store and overall job satisfaction. Part three questions consisted of communication and relationships factors of pharmacy technician job. It included pharmacy supervisors, relationship with coworkers and pharmacist interaction with other healthcare providers, customer interaction and overall job satisfaction. The questionnaire was made as an electronic format and it analyzed through survey monkey system about part one about pharmacy services units of pharmacy technician job. Results: The total responders were 96 . The gender distribution $83(86.46 \%)$ were males and $13(13.54 \%)$ were females. The majority of them $86(89.58 \%)$ were in age group (20-39 years). The average pharmacy technician satisfaction score of pharmacy management structure was (3.14), clinical pharmacy technician activities was (3.16), pharmacy technician satisfaction of pharmacy informatics was (2.76), pharmacy technician satisfaction score of pharmacy store factors were (2.87) and the overall job satisfaction was (3.62). The finding showed for factor there are no significant differences between male or female and social status married or single, experiences of current position and the most of salary income for all pharmacy services elements satisfaction ( $p>0.5)$. Conclusion: The pharmacy services with an emphasis on information technology and pharmacy inventory management affected negatively to the pharmacy technician job satisfaction. All pharmacy services satisfactions should be corrected to improve the pharmacy technician in the Kingdom of Saudi Arabia.

Keywords: Pharmacy, Practice, Factors, Pharmacy Technicians, Job, Satisfaction, Saudi Arabia.
\end{abstract}

\section{INTRODUCTION}

Over the past few years tremendous improvement has been observed in pharmacy services, including the pharmacy technicians activities, ${ }^{1}$ like intravenous admixture services, unit dose drug distribution system, total parenteral nutrition, Medications safety and computerized physician order entry. ${ }^{2-4}$ Generally, if any healthcare providers, including pharmacy technicians, face the pharmacy culture improvement, they will be satisfied with their job. Besides, the staff had more freedom of doing activities to improve the pharmacy services will enjoy the job performances. Dividing the pharmacist responsibility based on the dosage form (for the compounding of sterile and Non-Sterile) or based on patient care area (Inpatient pediatrics, adults, renal patients, cardiac and hepatic impaired patients, oncology patients, that was the drive for the pharmacists to communicates with the physicians and nurtures as member of the patient care team of the area that the pharmacist assigned to serve. That was giving the satisfaction to the pharmacist and he/ she validate his contribution as pharmacist that was the result after studying 6 years in university. ${ }^{5}$ During the pharmacist involvement with clinical team (Physician, Nurse) in inpatient area as personal efforts as clinical reference in regard of the medication's managements after the coordination with pharmaceutical care department leadership. So that was given the chance to attend the daily clinical rounds and attending the clinical discussion which was enriching the knowledge and increase the interest in readings which increase the experience in short period, since the reading was focused and from updated resources, that was the greatest source of job satisfaction, after the positive impression form the leader of the clinical team. ${ }^{6}$ Few studies discussed pharmacy technician job satisfaction with expanding and services improved..$^{7-10}$ Based on best of knowledge, the authors not familiar with any publications about this subject in the Kingdom of Saudi Arabia or Gulf and Middle East countries. The aim of the study to explore pharmacy technician's job satisfaction with an emphasis on pharmacy services in Saudi Arabia.

\section{METHODS}

It is a 4-months cross-section survey of the stress factors impact of pharmacy technician job satisfaction in Saudi Arabia. The study consisted of 35 questions divided into two-part demographic information and the second part consisted of three parts. Part one was about stress-related factors of 
pharmacy job. It included pharmacy management policies, pharmacy stress factors, pharmacy personal time, salary and benefits, pharmacy motivation factors. Part two included the questions about pharmacy services units of pharmacy job. It included pharmacy management structure, dispensing and patient education, clinical pharmacy services, pharmacy technology, pharmacy store and overall job satisfaction. Part three questions about communication and relationships factors of pharmacy technician job. It included pharmacy supervisors, relationship with coworkers and pharmacist interaction with other healthcare providers, customer interaction and overall job satisfaction. The 5-point Likert response scale system closed ended questions used. Several factors involved in the analysis of pharmacy technician's job satisfaction (gender, age, social status, experiences current position, salary). The questionnaire made as an electronic format and it analyzed through survey monkey system about part one in pharmacy services units of pharmacy technician job.

\section{RESULTS}

The total responders were 96. Of those 96 (100\%) was Saudi and $0(0 \%)$ was non-Saudi. The gender distribution $83(86.46 \%)$ were males and 13 (13.54\%) were females. The majority of them 86 (89.58 \%) were in age group (20-39 years). Most of the pharmacy technicians were married 67 (74.44\%) while $23(25.56 \%)$ were singles (Table 1). In an age group (3039 years) more male gender than age group (20-30 years) with significant differences $(p<0.05)$. While in age group $(20$ - 30 years) more female gender than the male with significant differences $(p<0.05)$. In an age group (30-39 years) more marriage than single status (20-30 years) with significant differences $(p<0.05)$. While in age group (20-30 years) more single than marriage status with significant differences $(p<0.05)$.

Most of the pharmacy technicians worked at outpatient pharmacy 50 (59.52\%) compared to inpatient pharmacy 24 (28.57\%). In all age categories, there are no significant differences between all categories at current pharmacy works $(p>0.5)$. Most of the responders spent less than three were $28(29.17 \%)$ three years, followed by six to ten years $26(27.08 \%)$ and three to five years $24(25.00 \%)$ and worked in the current position. In an age (30-39 years) more total years of experience ( $p>6$ years) in the current position than age group (20-30 years) with significant differences $(p<0.05)$. While in age group (20-30 years) more total years of experience ( $<3$ years) than age (30-39 years) with significant differences $(p<0.05)$.

While most of the responders receive 7,000-9,000 SR monthly salary 45 (47.87\%) and 10,000-12,000 SR monthly salary 32 (34.04\%) (Table 2). In an age (30-39 years) more salary (10,000 and above SR) than age (20-30 years) with significant differences $(p<0.05)$. While in age group $(20-30$ years) more salary $(7,000-9,000 \mathrm{SR})$ than age group (30-39 years) with significant differences $(p<0.05)$. In salary income $(10,000$ $12,000 \mathrm{SR})$ more marriage than salary income $(7,000-9,000 \mathrm{SR})$ with significant differences $(p<0.05)$. While in the salary income (7,000-9,000 SR) more singular than salary income $(10,000-12,000$ SR) with significant differences $(p<0.05)$. In salary income $(10,000-$ $12,000 \mathrm{SR}$ ) more working at the primary care center and continue to stay in the Pharmacy field than salary income (7,000-9,000 SR) with significant differences $(p<0.05)$. Most of the responders worked at Ministry of health $48(50 \%)$ followed by $\mathrm{MOH}$ government Hospital $24(25.00 \%)$ and private hospital $16(16.67 \%)$. In an age group (3039 years) more working at $\mathrm{MOH}$ than $\mathrm{MOH}$ hospitals (20-30 years) with significant differences $(p<0.05)$. While in age group (20-30 years) more $\mathrm{MOH}$ hospitals than $\mathrm{MOH}$ with significant differences $(p<0.05)$.

The responders worked at (< 50 beds) hospitals 14 (20.00\%) followed by (100-199 beds) 13 (18.57\%) and (200-299 beds) hospitals 11 (15.71\%) and the most hospitals were accredited by Saudi Commission for Health
Table 1: Demographic social information.

\begin{tabular}{|c|c|c|}
\hline Nationality & $\begin{array}{c}\text { Response } \\
\text { Count }\end{array}$ & $\begin{array}{c}\text { Response } \\
\text { Percent }\end{array}$ \\
\hline Saudi & 95 & $100.00 \%$ \\
\hline Non-Saudi & 0 & $0.00 \%$ \\
\hline Answered question & 95 & \\
\hline Skipped question & 1 & \\
\hline Gender & $\begin{array}{c}\text { Response } \\
\text { Count }\end{array}$ & $\begin{array}{c}\text { Response } \\
\text { Percent }\end{array}$ \\
\hline Male & 83 & $86.46 \%$ \\
\hline Female & 13 & $13.54 \%$ \\
\hline Answered question & 96 & \\
\hline Skipped question & 0 & \\
\hline Age & $\begin{array}{c}\text { Response } \\
\text { Count }\end{array}$ & $\begin{array}{c}\text { Response } \\
\text { Percent }\end{array}$ \\
\hline$<19$ & 0 & $0.00 \%$ \\
\hline $20-29$ & 36 & $37.50 \%$ \\
\hline $30-39$ & 50 & $52.08 \%$ \\
\hline $40-49$ & 10 & $10.42 \%$ \\
\hline $50-59$ & 0 & $0.00 \%$ \\
\hline$>60$ & 0 & $0.00 \%$ \\
\hline Answered question & 96 & \\
\hline Skipped question & 0 & \\
\hline Marital status & $\begin{array}{c}\text { Response } \\
\text { Count }\end{array}$ & $\begin{array}{c}\text { Response } \\
\text { Percent }\end{array}$ \\
\hline Single & 23 & $25.56 \%$ \\
\hline Married & 67 & $74.44 \%$ \\
\hline Other (please specify) & 0 & $0.00 \%$ \\
\hline Answered question & 90 & \\
\hline Skipped question & 6 & \\
\hline
\end{tabular}

Specialties 44 (57.14\%) followed by Saudi Central Board for Accreditation of Healthcare Institutions (CBAHI) 24 (31.17\%) and Joint commission of hospital accreditations USA 9 (11.69\%) (Table 3). In all age categories, there are no significant differences between all categories at hospital bed capacity $(p>0.5)$. The finding showed for gender factor there are no significant differences between male or female and social status (married or single), experiences of current position and most of salary income factors for all communication parameters $(p>0.5)$.

The average pharmacy technician satisfaction score of pharmacy management structure was (3.14). In the clinical pharmacy technicians' activities was (3.16), in an age (30-39 years) more participants disagree in drug use evaluation and participate in follow up and documentation of significant drug interactions than age (20-30 years) with significant differences $(p<0.05)$. The average pharmacy technicians satisfaction of pharmacy informatics was (2.76), in age group (20-30 years) more strongly agree of Pharmacy informatics meet the urgent requirement and had general satisfaction of Pharmacy informatics than age group (30-39 years) with significant differences $(p<0.05)$ and patient counselling satisfaction was (3.90) (Table 4 and 5). The average pharmacy technician's satisfaction score of pharmacy store factors were (2.87), In all age group categories, there are no significant differences between all categories at pharmacy medications storage satisfaction elements $(p>0.5)$. And the overall job satisfaction was (3.62), there are no significant differences 
Table 2: Demographic responder qualifications information.

\begin{tabular}{|c|c|c|}
\hline The practice area & $\begin{array}{l}\text { Response } \\
\text { Count }\end{array}$ & $\begin{array}{l}\text { Response } \\
\text { Percent }\end{array}$ \\
\hline Inpatient Pharmacy & 24 & $28.57 \%$ \\
\hline Outpatient Pharmacy & 50 & $59.52 \%$ \\
\hline Narcotics & 1 & $1.19 \%$ \\
\hline Extemporaneous Preparation & 1 & $1.19 \%$ \\
\hline Inventory Control & 0 & $0.00 \%$ \\
\hline Emergency pharmacy & 4 & $4.76 \%$ \\
\hline Drug Information & 0 & $0.00 \%$ \\
\hline All (All previous sections) & 2 & $2.38 \%$ \\
\hline PCC pharmacy & 2 & $2.38 \%$ \\
\hline Pharmacy licensees & 1 & $1.19 \%$ \\
\hline Answered question & 84 & \\
\hline Skipped question & 12 & \\
\hline $\begin{array}{l}\text { Total years you worked in current } \\
\text { position }\end{array}$ & $\begin{array}{l}\text { Response } \\
\text { Count }\end{array}$ & $\begin{array}{c}\text { Response } \\
\text { Percent }\end{array}$ \\
\hline$<3$ & 28 & $29.17 \%$ \\
\hline 3-5 & 24 & $25.00 \%$ \\
\hline 6-10 & 26 & $27.08 \%$ \\
\hline $11-15$ & 6 & $6.25 \%$ \\
\hline$>15$ & 12 & $12.50 \%$ \\
\hline Answered question & 96 & \\
\hline Skipped question & 0 & \\
\hline Monthly income & $\begin{array}{l}\text { Response } \\
\text { Count }\end{array}$ & $\begin{array}{c}\text { Response } \\
\text { Percent }\end{array}$ \\
\hline$<6.000$ & 2 & $2.13 \%$ \\
\hline $7.000-9.000$ & 45 & $47.87 \%$ \\
\hline $10.000-12.000$ & 32 & $34.04 \%$ \\
\hline $14,000-16,000$ & 9 & $9.57 \%$ \\
\hline $18,000-20,000$ & 5 & $5.32 \%$ \\
\hline$>25.000$ & 1 & $1.06 \%$ \\
\hline Answered question & 94 & \\
\hline Skipped question & 2 & \\
\hline
\end{tabular}

between all age categories at overall job satisfaction elements $(p>0.5)$ (Table 6 and 7). The finding showed for gender factor there are no significant differences between male or female and social status married or single, experiences of current position and the most of salary income for all pharmacy services elements $(p>0.5)$.

\section{DISCUSSION}

Job dissatisfaction of pharmacy technician is one of the key contributing factor towards decreased performance and enlarged turn over. The pharmacy technician's satisfaction with pharmacy management and structure does not reach the optimal level. That is related to most reasons, including the physical management arrangement for patient care was not appropriate and work schedule not sufficient for pharmacy technicians that's similar to previous study. ${ }^{7}$ When the duties and responsibilities are not clear through official policy describing the job description for day by day responsibilities and tasks that could lead to chaos in working environment, because the work load is there and the workflow is not clear.
Table 3: Demographic hospital information.

\begin{tabular}{|c|c|c|}
\hline Sector of work & $\begin{array}{c}\text { Response } \\
\text { Count }\end{array}$ & $\begin{array}{c}\text { Response } \\
\text { Percent }\end{array}$ \\
\hline Ministry of Health & 48 & $50.00 \%$ \\
\hline General Medical Directorate in Region & 2 & $2.08 \%$ \\
\hline MOH government Hospital & 24 & $25.00 \%$ \\
\hline Non- MOH government Hospital & 5 & $5.21 \%$ \\
\hline MOH-Primary Care Center & 1 & $1.04 \%$ \\
\hline Private Hospital & 16 & $16.67 \%$ \\
\hline Community pharmacy & 0 & $0.00 \%$ \\
\hline Other (please specify) & 0 & $0.00 \%$ \\
\hline Answered question & 96 & \\
\hline Skipped question & 0 & \\
\hline Number of beds at your hospital & $\begin{array}{c}\text { Response } \\
\text { Count }\end{array}$ & $\begin{array}{c}\text { Response } \\
\text { Percent }\end{array}$ \\
\hline$<50$ & 14 & $20.00 \%$ \\
\hline $50-99$ & 6 & $8.57 \%$ \\
\hline 100-199 & 13 & $18.57 \%$ \\
\hline 200-299 & 11 & $15.71 \%$ \\
\hline 300-399 & 9 & $12.86 \%$ \\
\hline $400-499$ & 5 & $7.14 \%$ \\
\hline 500-599 & 4 & $5.71 \%$ \\
\hline$=$ or $>600$ & 2 & $2.86 \%$ \\
\hline Medical City & 6 & $8.57 \%$ \\
\hline Answered question & 70 & \\
\hline Skipped question & 26 & \\
\hline The hospital accreditation & $\begin{array}{c}\text { Response } \\
\text { Count }\end{array}$ & $\begin{array}{c}\text { Response } \\
\text { Percent }\end{array}$ \\
\hline CBAHI & 24 & $31.17 \%$ \\
\hline Joint Commotion USA & 9 & $11.69 \%$ \\
\hline Canada & 0 & $0.00 \%$ \\
\hline Saudi commission of health accreditation & 44 & $57.14 \%$ \\
\hline Answered question & 77 & \\
\hline Skipped question & 19 & \\
\hline
\end{tabular}

So many of the institution recently develop clear job description for each working area and the success of that job description if it is designed to utilize the manpower properly through measurement of the workload and considering the available facilities. Scheduling the duties and responsibilities of the staff and to what extent the officer for developing flexible schedule that may suit the majority of the working staff and how he can (the officer) find incentives for the staff who are doing the hard duty shifts with coordination of the leadership of the department, which at the end will increase the staff satisfaction.

The pharmacy technicians were not fully satisfied with clinical pharmacy services as they did not participate in providing education for healthcare professionals and not share in the medical round because of those, not primary duties. Also, no assess in the drug use evaluation activities. Maybe most pharmacy technicians do not have any clinical activities or help clinical pharmacist duties. The clinical pharmacy technicians system should be implemented at healthcare institutions that may improve pharmacy technician job satisfaction as same as pharmacist showed in the previous studies. ${ }^{11,12}$ The revolution in the information technology 
Table 4: Pharmacy administration and clinical pharmacy satisfaction.

\begin{tabular}{|c|c|c|c|c|c|c|c|c|}
\hline & $\begin{array}{l}\text { Pharmacy management } \\
\text { structure }\end{array}$ & 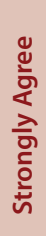 & $\frac{ఖ}{\frac{\Xi}{\leftarrow}}$ & 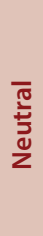 & 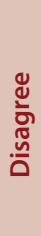 & 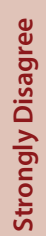 & 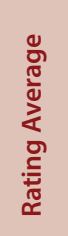 & 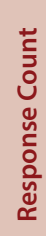 \\
\hline 1 & $\begin{array}{l}\text { My pharmacy } \\
\text { management software } \\
\text { system is overly } \\
\text { complicated to work with. }\end{array}$ & 16 & 18 & 29 & 26 & 6 & 3.13 & 95 \\
\hline 2 & $\begin{array}{l}\text { Management does } \\
\text { not make clear what } \\
\text { type of duties (patient } \\
\text { consultation, managerial, } \\
\text { dispensing) are expected } \\
\text { of me. }\end{array}$ & 21 & 23 & 28 & 20 & 3 & 3.41 & 95 \\
\hline 3 & $\begin{array}{l}\text { My work schedule is } \\
\text { flexible. }\end{array}$ & 9 & 30 & 25 & 17 & 12 & 3.08 & 93 \\
\hline 4 & $\begin{array}{l}\text { The physical arrangement } \\
\text { of the prescription area } \\
\text { facilitates communication } \\
\text { with patients. }\end{array}$ & 11 & 23 & 24 & 23 & 14 & 2.94 & 95 \\
\hline & Average & & & & & & 3.14 & \\
\hline
\end{tabular}

Answered question 95, Skipped question 1

\begin{tabular}{|c|c|c|c|c|c|c|c|c|}
\hline & $\begin{array}{l}\text { Clinical pharmacy } \\
\text { activities (I am satisfied } \\
\text { with ...) }\end{array}$ & 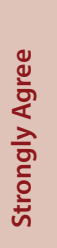 & ষัँ & $\begin{array}{l}\overline{0} \\
\text { एँ } \\
\text { zo }\end{array}$ & 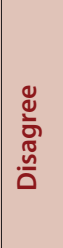 & 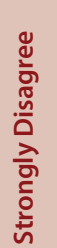 & 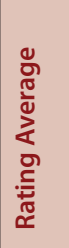 & 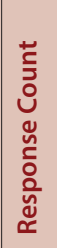 \\
\hline 1 & $\begin{array}{l}\text { Participating in drug-use } \\
\text { evaluation }\end{array}$ & 5 & 29 & 37 & 11 & 5 & 3.21 & 87 \\
\hline 2 & $\begin{array}{l}\text { Providing patient } \\
\text { education regarding drug } \\
\text { therapy }\end{array}$ & 13 & 30 & 28 & 8 & 9 & 3.34 & 88 \\
\hline 3 & $\begin{array}{l}\text { Participating in medical or } \\
\text { health care team rounds }\end{array}$ & 10 & 26 & 28 & 11 & 12 & 3.13 & 87 \\
\hline 4 & $\begin{array}{l}\text { Participating in the } \\
\text { detection, monitoring, } \\
\text { documentation, } \\
\text { management and } \\
\text { reporting of adverse drug } \\
\text { reactions }\end{array}$ & 12 & 28 & 29 & 9 & 10 & 3.26 & 88 \\
\hline 5 & $\begin{array}{l}\text { Providing educational } \\
\text { sessions or materials } \\
\text { for other health care } \\
\text { professionals }\end{array}$ & 14 & 18 & 20 & 17 & 21 & 2.86 & 90 \\
\hline & Average & & & & & & 3.16 & \\
\hline
\end{tabular}

Answered question 90, Skipped question 6
Table 5: pharmacy informatics and patient counselling satisfaction.

\begin{tabular}{|c|c|c|c|c|c|c|c|c|}
\hline & Information Technology & 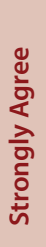 & 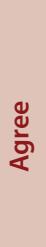 & $\begin{array}{l}\bar{\pi} \\
\stackrel{0}{2} \\
z\end{array}$ & 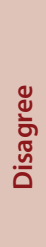 & 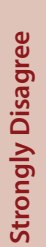 & 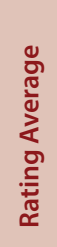 & 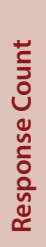 \\
\hline 1 & $\begin{array}{l}\text { Information Technology } \\
\text { department respond to } \\
\text { your urgent requirement } \\
\text { promptly. }\end{array}$ & 3 & 19 & 33 & 24 & 13 & 2.73 & 92 \\
\hline 2 & $\begin{array}{l}\text { You are satisfied } \\
\text { with overall services } \\
\text { provided by Information } \\
\text { Technology department } \\
\text { to you. }\end{array}$ & 3 & 19 & 37 & 21 & 12 & 2.78 & 92 \\
\hline & Average & & & & & & 2.76 & \\
\hline
\end{tabular}

Answered question 93, Skipped question 3

\begin{tabular}{|c|c|c|c|c|c|c|c|c|}
\hline & $\begin{array}{l}\text { Dispensing vs. patient } \\
\text { consultation duties }\end{array}$ & 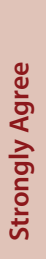 & 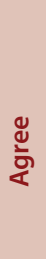 & $\begin{array}{l}\overline{\widetilde{\pi}} \\
\overline{3} \\
\text { z }\end{array}$ & 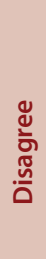 & 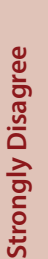 & 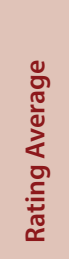 & 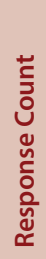 \\
\hline 1 & $\begin{array}{l}\text { I do not have enough time } \\
\text { to perform many patient } \\
\text { consultation duties at my } \\
\text { job. }\end{array}$ & 24 & 31 & 22 & 15 & 2 & 3.64 & 94 \\
\hline 2 & $\begin{array}{l}\text { Patients are only } \\
\text { concerned about getting } \\
\text { their medication as } \\
\text { cheaply / quickly as } \\
\text { possible. }\end{array}$ & 43 & 32 & 11 & 7 & 1 & 4.16 & 94 \\
\hline & Average & & & & & & 3.90 & \\
\hline
\end{tabular}

Answered question 94, Skipped question 2

and automation in the pharmaceutical care services is tremendous. One of the limitations for the automation in the field that it needs the involvement of the pharmacist as expert in the medication management which needed to assist in operating and maintaining those software or equipment and introducing them to practice in a practical way by pharmacy technician that assure the patient safety with proper cost saving. In the current study the pharmacy technicians are not satisfied with Pharmacy informatics that's related to computerized system not responding or meeting the urgent situation and informatics services not fully implemented with pharmacy technicians. Maybe the pharmacy Informatics program with pharmacy technicians involved is required to improve pharmacy technician job satisfaction. ${ }^{13}$

The pharmacy technicians showed acceptable satisfaction with patient education as part of clinical pharmacy activities similar to pervious pharmacist job satisfaction studies. ${ }^{11,12}$ The pharmacy technicians were satisfied when they challenged in patient care through giving the essential information related to medication(s) either through direct contact with the patient or when the information needed by physician or nurse 
Table 6: pharmacy inventory management satisfaction.

\begin{tabular}{|c|c|c|c|c|c|c|c|c|}
\hline & Store Related Issues & 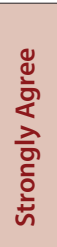 & $\begin{array}{l}\text { むँ } \\
\text { क्ष }\end{array}$ & 胥 & 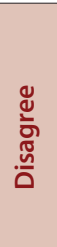 & 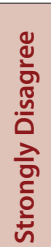 & 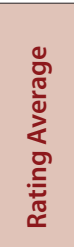 & 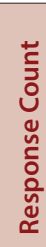 \\
\hline 1 & $\begin{array}{l}\text { The availability of } \\
\text { pharmaceutical items } \\
\text { (percentage of items } \\
\text { received compared to } \\
\text { ordered) was } 90 \% \text { or more } \\
\text { most of the times }\end{array}$ & 5 & 35 & 29 & 16 & 10 & 3.09 & 95 \\
\hline 2 & $\begin{array}{l}\text { The availability of non- } \\
\text { pharmaceutical items } \\
\text { (percentage of items } \\
\text { received compared to } \\
\text { ordered) was } 90 \% \text { or more } \\
\text { most of the times }\end{array}$ & 4 & 21 & 38 & 25 & 7 & 2.89 & 95 \\
\hline 3 & $\begin{array}{l}\text { The item shortages } \\
\text { that you have is similar } \\
\text { in other hospitals } \\
\text { pharmacies }\end{array}$ & 7 & 41 & 23 & 16 & 8 & 3.24 & 95 \\
\hline 4 & $\begin{array}{l}\text { When you have urgent } \\
\text { order, you receive the } \\
\text { goods from store within } \\
24 \mathrm{hr} \text { in most cases }\end{array}$ & 6 & 29 & 16 & 23 & 21 & 2.75 & 95 \\
\hline 5 & $\begin{array}{l}\text { You have regular update } \\
\text { from store about new } \\
\text { products in the market }\end{array}$ & 3 & 14 & 30 & 26 & 19 & 2.52 & 92 \\
\hline 6 & $\begin{array}{l}\text { You have regular update } \\
\text { from store about the } \\
\text { shortages in the market }\end{array}$ & 3 & 19 & 27 & 24 & 20 & 2.58 & 93 \\
\hline 7 & $\begin{array}{l}\text { warehouse take your } \\
\text { undelivered items } \\
\text { seriously }\end{array}$ & 7 & 21 & 39 & 13 & 12 & 2.98 & 92 \\
\hline 8 & $\begin{array}{l}\text { You are satisfied with } \\
\text { overall services provided } \\
\text { by warehouse to you }\end{array}$ & 2 & 32 & 27 & 22 & 11 & 2.91 & 94 \\
\hline & Average & & & & & & 2.87 & \\
\hline \multicolumn{9}{|c|}{ Answered question 95, Skipped question 1} \\
\hline
\end{tabular}

or for drug evaluation. Patient counseling is one of the most interested tasks done by the pharmacist, as a result from this survey and forms the discussions with our colleges that were the most popular task for the pharmacist to do since it will give him a chance to deliver the information related to his medication or treatment plan through a professional way. The heavy working load environment and the lacking in the community for the important role of the pharmacy as source of the drug information. As results, in the study showed the pharmacy technicians do not have time for patient education. The pharmacy technicians wish to participate in the patient counseling of their medications, but there is no time for that. Work schedule with time arrange may solve the problems. The pharmacy technicians had poor satisfaction with pharmacy storage in most aspects. The most aspects were the Pharmacy store not informed the pharmacy technicians about new medications or shortage of medications in the market. The pharmacy inventory management system should revise and implement accordingly. The pharmacy technician's job
Table 7: The overall pharmacy technicians job satisfaction.

\begin{tabular}{|c|c|c|c|c|c|c|c|c|}
\hline & $\begin{array}{l}\text { Overall job } \\
\text { satisfaction }\end{array}$ & 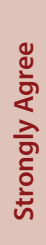 & 㐫 & $\begin{array}{l}\overline{0} \\
\frac{0}{3} \\
\text { Z }\end{array}$ & 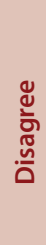 & 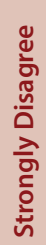 & 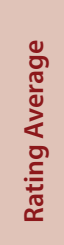 & 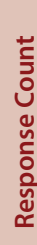 \\
\hline 1 & $\begin{array}{l}\text { I find challenge in } \\
\text { my work. }\end{array}$ & 33 & 37 & 15 & 11 & 0 & 3.96 & 96 \\
\hline 2 & $\begin{array}{l}\text { Knowing what I } \\
\text { know now, if I had to } \\
\text { decide all over again } \\
\text { whether to go into } \\
\text { pharmacy, I would } \\
\text { choose another field. }\end{array}$ & 25 & 14 & 12 & 26 & 19 & 3.0 & 96 \\
\hline 3 & $\begin{array}{l}\text { If I were free to } \\
\text { pursue any type of } \\
\text { career I wanted, } \\
\text { I would stay in } \\
\text { pharmacy. }\end{array}$ & 32 & 35 & 20 & 5 & 4 & 3.9 & 96 \\
\hline
\end{tabular}

satisfaction was acceptable, despite had several challenges. In the past, they would change their pharmacy field, but currently, they wish to continue on Pharmacy specialty. That is related to spending extended time and it is difficult to change now. It's wastage of time and money. Some of our health care institutions purchase ready platform for operating software to be used to run and document the daily activity. This software supposed to be supported to facilitate the workflow and the documentation process, while this software needs time to be customized according to the need of each department because it is tough to find software meet the specific demand of each department of the health institution. The difficulties and the time will be a factor of dissatisfaction when the support and maintenance of this software needed.

\section{CONCLUSION}

Pharmacy technician's job satisfaction was affected negatively with absent of clinical pharmacy services, patient counseling services and pharmacy informatics. Targeting of corrections of pharmacy services affected positively the pharmacy technician's job satisfaction in the Kingdom of Saudi Arabia.

\section{ACKNOWLEDGEMENT}

None.

\section{CONFLICT OF INTEREST}

The authors declare that there are no conflicts of interest.

\section{ABBREVIATIONS}

KSA: Kingdom of Saudi Arabia; MOH: Ministry of Health; B.Sc. Pharm: Bachelor in pharmacy; Pharm D: Doctor of Pharmacy; CBAHI: Saudi Central Board for Accreditation of Healthcare Institutions.

\section{ORCID ID}

Yousef Ahmed Alomi (iD https://orcid.org/0000-0003-1381-628X 


\section{REFERENCES}

1. Alomi YA, Alghamdi SJ, Alattyh RA, Elshenawy RA. The Evaluation of Pharmacy Strategic Plan in Past 2013-2016 and Forecasting of New Vision 2030 at Ministry of Health in Saudi Arabia. J Pharm Pract Community Med. 2018;4(2):93-101.

2. Alomi YA. National Intravenous (IV) Therapy Program at $\mathrm{MOH}$ in Saudi Arabia. EC Pharm Sci. 2016;3(2-3):307-11.

3. Alomi YA. National Total Parenteral Nutrition Program at $\mathrm{MOH}$ in Saudi Arabia. EC Nutr. 2016;3(5):697-9.

4. Alomi YA, Alghamdi SJ, Alattyh RA. National Survey of Pharmacy Practice at $\mathrm{MOH}$ Hospitals in Saudi Arabia 2016-2017: Pharmacy Computerized and Technology. J Pharm Pract Community Med. 2018;4(1s):s40-6.

5. Hardigan PC, Carvajal MJ. Application of Rasch rating scale model to analysis of job satisfaction among practicing pharmacists. J Am Pharm Assoc. 2008;48(4):522-9

6. Hardigan PC, Sangasubana N. A latent class analysis of job satisfaction and turnover among practicing pharmacists. Res Soc Adm Pharm. 2010;6(1):32-8.

7. Coburn MJ, Gagnon JP, Eckel FM. Job satisfaction of hospital pharmacy technicians in North Carolina. Am J Heal Pharm. 1980;37(3):359-64.

8. Sanford ME, Facchinetti NJ, Broadhead RS. Observational study of job satisfaction in hospital pharmacy technicians. Am J Heal Pharm. 1984;41(12):2599-606.

9. Cortese LM, Greenberger DW, Schneider PJ, Bourret JA. Job characteristics and satisfaction of pharmacy technicians. Am J Heal Pharm. 1987;44(11):2514-8.

10. Mahoney CD, Gallina JN, Jeffrey LP. A comprehensive program to increase job satisfaction among pharmacy technicians. Hosp Pharm. 1982;17(10):547-50.

11. Lawson KA. Satisfaction and involvement in clinical activities. Am J Heal Pharm. 1996;53(3):281-4

12. Rauch TM. Job satisfaction in the practice of clinical pharmacy. Am J Public Health. 1981;71(5):527-9.

13. Humphries TL, Delate T, Helling DK, Richardson B. Impact of an automated dispensing system in outpatient pharmacies. J Am Pharm Assoc. 2008:48(6):774-9. 